\title{
CLEAVAGE RATE OF MOUSE EGGS FROM INDUCED AND SPONTANEOUS OVULATION
}

\author{
JULIA ALLEN* AND ANNE MCLAREN $\dagger$ \\ Institute of Animal Genetics, University of Edinburgh
}

(Received 22nd April 1971)

\begin{abstract}
Summary. The cleavage rate of mouse eggs was not affected by whether ovulation was spontaneous or induced, nor by the age of the mother, nor by the number of eggs shed, though spontaneously ovulated eggs were consistently about half a cleavage division less advanced than those from induced ovulation, suggesting that cleavage had begun about $5 \mathrm{hr}$ later. The number of eggs recovered showed a significant decline from the 2nd to the 4th day of pregnancy in adult but not in immature mice.
\end{abstract}

When ovulation and mating are induced by treatment of mice with gonadotrophic hormones, the resulting blastocysts are equal in viability and developmental potential to those recovered after spontaneous ovulation (Gates, 1956; McLaren \& Michie, 1956). Earlier developmental stages, however, have not been studied from this point of view. Since gonadotrophin treatment is increasingly used to obtain mouse eggs for culture of preimplantation stages, we have examined the viability and rate of development of eggs (a) obtained from induced ovulation versus spontaneous ovulation, (b) from induced ovulation of adult versus immature animals, and (c) in relation to the number of eggs shed, which depends on the dose of PMSG used to induce ovulation.

Mice of the randomly bred $Q$ strain were fed on a standard pellet diet, and maintained at $72 \pm 2^{\circ} \mathrm{C}$. Ovulation was induced by the intraperitoneal injection of 1 or 6 i.u. PMs (Gestyl; Organon) at 17.00 hours, followed $43 \mathrm{hr}$ later (12 midday) by the intraperitoneal injection of $1 \mathrm{i}$.u. HGG (Pregnyl; Organon). The females were then paired with males of tested fertility and examined the following morning for copulation plugs. The day on which a plug was found was reckoned to be the 1st day of pregnancy. Since sexual maturity in Q-strain females occurs at about 5 weeks of age, 4-week-old females were used for the immature group and 6-week-old females for the adult group.

Eggs were recovered by flushing the reproductive tract with phosphatebuffered saline. They were classified as normal or abnormal, and cell counts were made in the normal embryos. Two females contained no normal eggs and have been omitted. Up to the four-cell stage, cells were counted by examination under a dissecting microscope. Later stages were prepared by the air-drying technique of Tarkowski (1966), stained with lactic acetic orcein and examined with the aid of a camera lucida microscope attachment.

* Present address: Biology Department, University of South Carolina, Columbia, South Carolina 29208.

† Agricultural Research Council Unit of Animal Genetics. 
Cell numbers were subjected to logarithmic transformation for purposes of statistical analysis, since Bowman \& McLaren (1970) showed that the logarithm of cell number increases in a linear manner with time, from the two-cell to the blastocyst stage. Variation among females was clearly greater than variation among embryos within females; the cell counts were therefore averaged for each female, and mean cell number used as the unit of analysis, weighting where appropriate for the number of eggs on which the mean was based.

Table 1 shows the numbers of eggs recovered in the four groups on the 2nd, 3rd and 4th days of pregnancy. The mice primed with a low level of PMSG produced about the same number of eggs as those ovulating spontaneously;

TABLE 1

THE NUMBER OF EGGS (MEAN \pm STANDARD ERROR) REGOVERED ON THE 2ND, 3RD AND 4TH DAY OF PREGNANCY, FOLLOWING SPONTANEOUS (GROUP I) OR INDUCED (GROUPS 2 to 4) OvUlation

\begin{tabular}{|c|c|c|c|c|}
\hline & $2 n d d a y$ & $3 r d d a y$ & 4th day & Overall \\
\hline $\begin{array}{l}\text { Group } 1 \text { (control) } \\
\text { No. of mice }\end{array}$ & 6 & 6 & 6 & 18 \\
\hline $\begin{array}{l}\text { Mean no. of eggs } \\
\text { Mean no. of normal eggs }\end{array}$ & $\begin{array}{l}13.50 \pm 1 \cdot 12 \\
10.00 \pm 1.32 \\
\end{array}$ & $\begin{array}{r}11 \cdot 00 \pm 1 \cdot 18 \\
9 \cdot 33 \pm 0.84 \\
\end{array}$ & $\begin{array}{r}10 \cdot 00 \pm 1 \cdot 34 \\
9 \cdot 50 \pm 1 \cdot 28 \\
\end{array}$ & $\begin{array}{r}11 \cdot 50 \pm 0.73 \\
9 \cdot 61 \pm 0.64 \\
\end{array}$ \\
\hline $\begin{array}{l}\text { Group } 2 \text { (young, low dose) } \\
\text { No. of mice }\end{array}$ & 4 & 4 & 6 & 14 \\
\hline $\begin{array}{l}\text { Mean no. of eggs } \\
\text { Mean no. of normal eggs }\end{array}$ & $\begin{array}{l}11 \cdot 25 \pm 1 \cdot 49 \\
10 \cdot 75 \pm 1 \cdot 25 \\
\end{array}$ & $\begin{array}{l}5 \cdot 75 \pm 1 \cdot 80 \\
5 \cdot 50 \pm 1 \cdot 89\end{array}$ & $\begin{array}{l}12 \cdot 33 \pm 1 \cdot 65 \\
12 \cdot 17 \pm 1 \cdot 72 \\
\end{array}$ & $\begin{array}{r}10 \cdot 14 \pm 1 \cdot 19 \\
9 \cdot 86 \pm 1 \cdot 20 \\
\end{array}$ \\
\hline $\begin{array}{l}\text { Group } 3 \text { (young, high dose) } \\
\text { No. of mice }\end{array}$ & 5 & 6 & 6 & 17 \\
\hline $\begin{array}{l}\text { Mean no. of eggs } \\
\text { Mean no. of normal eggs }\end{array}$ & $\begin{array}{l}18 \cdot 00 \pm 3 \cdot 79 \\
11 \cdot 00 \pm 2 \cdot 98\end{array}$ & $\begin{array}{l}25 \cdot 33 \pm 5 \cdot 45 \\
23 \cdot 33 \pm 4 \cdot 97\end{array}$ & $\begin{array}{l}20 \cdot 67 \pm 4 \cdot 43 \\
19 \cdot 17 \pm 3 \cdot 21\end{array}$ & $\begin{array}{l}21 \cdot 53 \pm 2 \cdot 66 \\
18 \cdot 24 \pm 2 \cdot 46\end{array}$ \\
\hline $\begin{array}{l}\text { Group } 4 \text { (adult, high dose) } \\
\text { No. of mice }\end{array}$ & 10 & 5 & 6 & 21 \\
\hline $\begin{array}{l}\text { Mean no. of eggs } \\
\text { Mean no. of normal eggs }\end{array}$ & $\begin{array}{l}30 \cdot 70 \pm 2 \cdot 92 \\
22 \cdot 70 \pm 3 \cdot 08\end{array}$ & $\begin{array}{l}21 \cdot 60 \pm 5 \cdot 74 \\
13 \cdot 00 \pm 5 \cdot 84\end{array}$ & $\begin{array}{l}14 \cdot 17 \pm 2 \cdot 81 \\
12 \cdot 33 \pm 3 \cdot 29\end{array}$ & $\begin{array}{l}23 \cdot 81 \pm 2 \cdot 55 \\
17 \cdot 43 \pm 2 \cdot 39\end{array}$ \\
\hline
\end{tabular}

the mice that received the high PMSG dose produced about twice this number of eggs. The mean number of eggs recovered decreased with time in both groups of adult females $(P<0.05$ for Group I; $P<0.01$ for Group 4). Presumably, some of the eggs present on the 2 nd day had degenerated by the 4th day and were not recovered. The decrease with time was clearly greater $(P<0.05)$ in the superovulated adults of Group 4 than in the control females; the superovulated adults also differed significantly $(P<0.05)$ from the superovulated immature females, which showed no effect of time.

These findings suggest that loss of eggs occurs during cleavage in the adult reproductive tract, and that crowding increases this loss. They are consistent with the observation of Bowman \& Roberts (1958) that the proportion of mouse eggs subsequently represented by implantation sites is inversely proportional to the number shed. Competition at the time of implantation seemed an unlikely explanation of this effect, since McLaren \& Michie (1959) observed that the proportion of transferred blastocyts that implanted was not affected by 
TABLE 2

THE NUMBER OF GELLS PER EMBRYO AT VARIOUS INTERVALS AFTER SPONTANEOUS OVULATION (GROUP 1) OR OVULATION INDUCED WITH GONADOTROPHIG HORMONES (GROUPS 2 TO 4)

\begin{tabular}{l|cc|cc|cc}
\hline & \multicolumn{2}{|c|}{$2 n d$ day } & \multicolumn{2}{c|}{ 3rd day } & \multicolumn{2}{c}{ 4th day } \\
& $a . m$. & $p . m$. & $a . m$. & $p . m$. & a.m. & $p . m$. \\
\hline Group 1 & $2 \cdot 0^{*}$ & $2 \cdot 0$ & $4 \cdot 9$ & $7 \cdot 6$ & $29 \cdot 3$ & $47 \cdot 6$ \\
$\quad$ (control) & $(35)$ & $(25)$ & $(31)$ & $(23)$ & $(19)$ & $(13)$ \\
Group 2 & $2 \cdot 1$ & $2 \cdot 8$ & $6 \cdot 4$ & $11 \cdot 8$ & $56 \cdot 6$ & $55 \cdot 2$ \\
$\quad$ (young, low dose) & $(24)$ & $(19)$ & $(14)$ & $(8)$ & $(18)$ & $(30)$ \\
Group 3 & $2 \cdot 0$ & $2 \cdot 0$ & $6 \cdot 4$ & $11 \cdot 0$ & $38 \cdot 1$ & $64 \cdot 0$ \\
$\quad$ (young, high dose) & $(34)$ & $(21)$ & $(74)$ & $(29)$ & $(32)$ & $(51)$ \\
Group 4 & $2 \cdot 2$ & $2 \cdot 1$ & $7 \cdot 0$ & $12 \cdot 3$ & $56 \cdot 2$ & $37 \cdot 9$ \\
(adult, high dose) & $(88)$ & $(139)$ & $(29)$ & $(17)$ & $(22)$ & $(21)$ \\
\hline
\end{tabular}

* Mean cell numbers were calculated on logarithmically transformed data and antilogarithms taken for tabular presentation. The number of embryos on which the mean is based is given in parentheses.

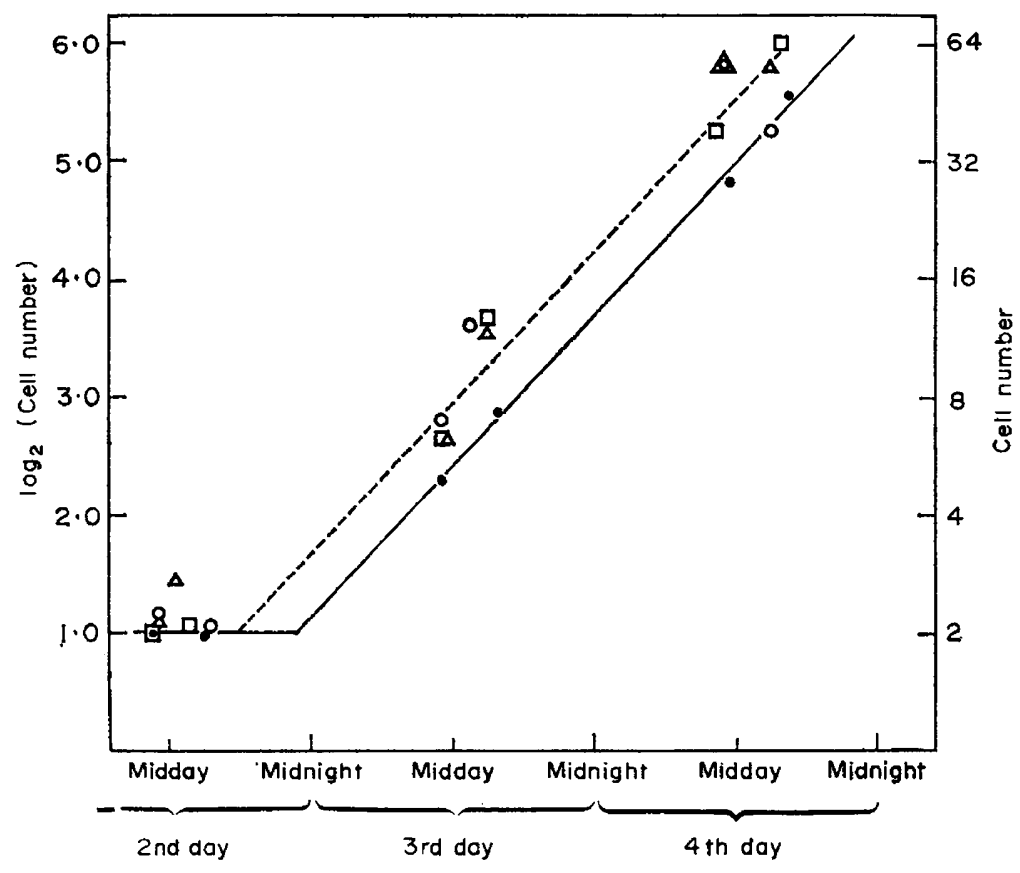

Text-rIG. 1. Cleavage rate of $Q$-strain mouse eggs during the first 4 days of gestation. - Adult females, spontaneous ovulation; $O$, adult females, induced ovulation, high PMSG dose; $\square$, young females, induced ovulation, high PMSG dose; $\triangle$, young females, induced ovulation, low PMSG dose. Regression lines have been fitted to the 3rd and 4th day data from the spontaneous ovulation (-) and the induced ovulation (- - - $)$ groups separately, using the pooled, within-group regression coefficient $(b=+0 \cdot 1068 \pm 0 \cdot 0066)$. 
the number transferred (in the range 0 to 30 ). The present data support the conclusion that, when the number of eggs is large, greater proportional loss occurs during cleavage.

The data on cell number are presented in Table 2 and Text-fig. 1. The three groups in which ovulation was induced showed no significant differences from each other. On the other hand, at each of the six time intervals listed in Table 2 , the eggs from induced ovulation (three groups pooled) contained more cells than did the spontaneously ovulated controls, significantly so on the afternoon of the 3rd and the morning of the 4th day. The control data plotted in Textfig. I suggest a plateau at the two-cell stage (as found by Graham, 1971), followed by a linear increase in cell number. Regression analyses were therefore performed for the 3rd and 4th day data. No significant differences in slope were found, and the estimated doubling time $\left(9 \frac{1}{2} \mathrm{hr}\right.$ ) agrees well with the $10 \mathrm{-hr}$ doubling time reported by Bowman \& McLaren (1970) for the same strain of mice. The position of the regression lines did not differ significantly among the induced ovulation groups; the combined regression line for these groups lay significantly above that for the spontaneously ovulated group $(P<0.02)$.

Thus, eggs from induced ovulation, irrespective of the age of the female and the dose of hormone, cleaved at the same rate as spontaneously ovulated eggs but appeared to begin cleaving about $5 \mathrm{hr}$ earlier. This led to a large difference in cell number by the morning of the 4th day (Table 2). The highest individual cell counts (up to 128 cells) were in blastocysts from young females that received 1 i.u. of PMSG. The difference in time of initiation of cleavage could have been due to an earlier time of ovulation in the hormone-treated mice, or to a shorter interval between ovulation and first cleavage. HCG was given at 12 midday BST, in order to produce ovulation about $12 \mathrm{hr}$ later, i.e. about midnight. Spontaneous ovulation is usually assumed also to occur soon after midnight, but may be related to the time of sunset, which, in Edinburgh during June and July when this experiment was done, occurs at about 22.00 hours BST. Our results are consistent with the occurrence of spontaneous ovulation at 04.00 or 05.00 hours BST.

We are grateful to the Ford Foundation for financial assistance.

\section{REFERENCES}

Bowman, J. C. \& Roberts, R. G. (1958) Embryonic mortality in relation to ovulation rate in the house mouse. 7. exp. Biol. 35, 138.

Bowman, P. \& McLaren, A. (1970) Cleavage rate of mouse embryos in vivo and in vitro. F. Embryol. exp. Morph. 24, 203.

Gates, A. H. (1956) Viability and developmental capacity of eggs from immature mice treated with gonadotrophins. Nature, Lond. 177, 754.

Graham, G. F. (1971) Nucleic acid metabolism during early mammalian development. In: Regulation of Mammalian Reproduction. National Institutes of Health. (in press).

MCLAREN, A. \& Michie, D. (1956) Studies on the transfer of fertilized mouse eggs to uterine fostermothers. (1) Factors affecting the implantation and survival of native and transferred eggs. $\mathcal{F}$. exp. Biol. 33, 394.

MaLaren, A. \& Michie, D. (1959) Studies on the transfer of fertilized mouse eggs to uterine fostermothers. (2) The effect of transferring large numbers of eggs. 7. exp. Biol. 36, 40.

TARkowski, A. K. (1966) An air-drying method for chromosome preparation from mouse eggs. Cytogenetics, 5, 394. 